\title{
Inter-American System of Human Rights - A Critical Analysis
}

\author{
Muhammad Nasir Uddin, Md Yasin Khan Chowdhury, Md. Easin \\ * Lecturer, Department of Law, International Islamic University Chittagong. \\ * Senior Lecturer, Department of Law, Southern University Bangladesh. \\ * Senior Lecturer, Department of Law, Southern University Bangladesh.
}

\section{Introduction:}

The Organization of American States ${ }^{1}$ as established in the ninth Inter-American Conference held in Bogota in 1948 is the old regional mechanism to protect human rights. The development of the inter-American system followed a different path from that of its European counter part. Although the institutional structure is superficially similar, and the normative provisions are in most respects very similar, the conditions under which the two systems developed were radically different. This paper explores a critical analysis of the Inter-American Human Rights System as a whole based on a comparative study between the Inter-American system of human rights protection and the European Version of Human Rights protection.

\section{Background:}

The Inter- American system of human rights protection possesses a distinctive dual structure. All American states which are members of the OAS have human rights obligations under the Charter, while some voluntarily assume obligations through the American Convention on Human Rights. The two strands of protection do not, however, stand alone, but interact and may, at certain points, be regarded as symbiotic. They share a common institution in the Inter American Commission on Human Rights, which discharges different functions with respect to both the Charter and the Convention. And while the court is essentially a creature of the convention, it too has certain jurisdictional competences regarding the Charter by virtue of the exercise of its exceptionally broad advisory jurisdiction under Article 64 of the Convention. One writer ${ }^{2}$ has described it as:

"In the OAS system, human rights are protected under two interrelated frameworks. The first is founded upon charter . . . and the 1948 American Declaration of the Rights and Duties of Man. The second, and more effective, is founded upon the American Convention of Human Rights ... The Convention is applicable to only those states that have ratified it, whereas the Declaration is applicable to all OAS member states".

Thus the Inter-American human rights system has two distinct legal sources: one has evolved from the Charter of the Organization of American States (OAS); the other is based on the American Convention on Human Rights ${ }^{3}$. The Charter-based system applies to all 35 Member States of the OAS. The Convention system is legally binding only on the States Parties to it. The two systems overlap and interact in a variety of ways. The Convention guarantees some two dozen broad categories of civil and political human rights and freedoms. On the other hand, the European Human Rights Convention comprises 13 human rights. The reason behind this is quite understandable. The situations in Europe is vey favourable to flourish with political stability and practiced democracy whereas the Latin America was the region of totalitarian due to the poverty, illiteracy and autocratic governments.

\section{The Inter-American Commission on Human Rights:}

The Commissions only became an organ of the OAS following the amendment of the Charter by the Protocol of Buenos Aires in 1976. Prior to that, it was simply an autonomous entity of the Organization which had been created by a resolution of the fifth Meeting of Consultation of the Ministers of Foreign Affairs at Santiago in $1959^{4}$. Although the Commission at that time was clearly not an organ of the OAS it achieved substantial progress in executing its mandate within a short period of time despite its indefinite legal status.

\footnotetext{
${ }^{1}$ The notion of an international union in the New World was first put forward by Simón Bolívar who, at the 1826 Congress of Panama (still being part of Colombia), proposed creating a league of American republics, with a common military, a mutual defense pact, and a supranational parliamentary assembly. See "Panama: A Country Study". Washington: GPO for the Library of Congress, 1987.

${ }^{2}$ Willem-Jan Van Der Wolf, Indigenous Peoples Rights in International Law, 4 Global Journal of Human Rights Review,87,107(1991).

${ }^{3}$ American Convention on Human Rights, 22 November 1969, O.A.S.T.S. No. 36 (entered into force 27

August 1978) [Convention].

${ }^{4}$ Thomas Burgenthal, the revised OAS Charter and the protection of human Rights, (1975) American Journal of international Law, Vol-69.
} 
Chapter XVIII of the amended Charter comprises only one provision, Article 112, which provides that the principal function of the Commission is to promote the observance and protection of human rights and to serve as a consultative organ of the Organization in these matters. This is a broad mandate which is further amplified by the Commission's Statute and Rules of Procedure. It should also be noted at this point that the Commission serves not only Convention on Human Rights.

\section{The institutional structure of the American Convention :}

The convention mandates two organs to supervise the implementation and enforcement of the rights contained therein. These are the Commission and the court. Both institutions have specially assigned functions under the Convention, but the contentious jurisdiction of the Court in individual applications under Article 44 is predicated upon the exhaustion of procedures before the Commission. It is intended here to examine the functions and procedures of the Commissions as a Convention institution, since its relationship with the court in both contentious and advisory cases will be addressed in detail later.

The role of the Commissions as a Charter institution has already been considered briefly above. As a Convention institution, its multifaceted role is defined by Article 41. Briefly stated this is educational, investigative, advisory, administrative and supervisory. These tasks are complementary and mutually supporting, and permit the Commission to oversee the whole range of human rights activities in the American states. The Commission's competence therefore includes the conduct of country studies and reports, on-site investigations and the operation of the complaint machinery contained in the Conventions.

\section{The Complaint Machinery:}

There are two categories of complaints which may be made under the Convention. ${ }^{5}$ The first is complaints by persons denouncing violations of the Convention by a state party under Article 44 of the Convention. The second is complaints by states parties that another state party has violated the human rights protected by the Convention under Article 45. In analyzing Article 44 two important points should be noted. First, all states which become party to the American Convention automatically recognize the competence of the Commissions to receive complaints from persons alleging violation of their rights. This differs from the European Convention which requires a declaration by a state party that it recognizes the competence of the European Commission to receive petitions by victims alleging violation of their rights ${ }^{6}$. Indeed, the Court itself has described the American Convention as unique among human rights instruments in making the right of private petition applicable against states parties as soon as they ratify the Convention. Second, while under the European Convention, only victims may author petitions, under Article 44 of the American Convention:

"Any person or group of persons, or any nongovernmental entity legally recognized in one or more member states of the Organization, may lodge petitions with the Commission containing denunciations or complaints of violation of this Convention by a State Party."

This is clearly drafted in wide terms and avoids the problems encountered by the European Commission in determining whether petitions may be received from persons who are themselves clearly not victims, but who are petitioning on behalf of alleged victims. Indeed it is clear that while the European Convention does not permit active polarity, the American Convention does.

In considering the second inter state system of complaints, it is clear that the European Convention makes inter state complaints mandatory. For state parties, the American Convention requires states wishing to allow such complaints to make a declaration to that effect under Article 45. Even then, complaints may only be instituted on the basis of strict receiprocity. The reason for making inter state complaints an exception rather than the rule under the Convention probably derives from the likely political sensitivity attached to such action in a hemisphere with widely differing political and social structures. It is clear that an inter state petition system could be abused by states wishing to make political capital out of disputes over alleged human rights violations. Indeed, under the European system, the majority of the relatively few inter-state applications appear to have been motivated by some political hostility or ill-will. It might also be noted that the inter- state complaint procedure in Article 41 of the International Covenant on Civil and Political Rights has never been invoked by any of the states parties to it. At this point of discussion, some weaknesses regarding the Court's jurisdiction are pointed out.

\section{Lack of the Court's Contentious Jurisdiction:}

It is perhaps an abuse of speech to refer to the lack of use of the court's contentious jurisdiction. It is possibly more accurate to describe the prevailing situation as one of non-use. The reason why the court has been presented with so few contentious cases is probably explicable by reference to a number of factors, not all of

\footnotetext{
${ }^{5}$ For a historical evolution of the system and the different mechanisms it uses, see Robert K. Goldman,"History and Action: The InterAmerican Human Rights System and the Role of the Inter-American Commission on Human Rights" (2009) 31 no. 4 Hum. Rts. Q. 856. ${ }^{6}$ Article 25 of the European Convention.
} 
them exclusive to the Americas. There are at least three generic factors to which one can point as hindering the full exercise of the Court's contentious jurisdiction. First, the problems inherent in developing the international protection of human rights within the international legal system, secondly, the political and social problems of much of the Western Hemisphere and thirdly, problems in the structure of the Convention itself ${ }^{7}$.

The major problem in developing any system of international human rights protection is that states jealously guard their national sovereignty that is their right to order their internal affairs as they see fit. The only limits imposed upon a state's competence in its internal affairs are through norms of international law which remove certain matters from a states domestic jurisdiction to the international plane. Those matters not removed from the exclusive jurisdiction of a state in breach. Matters not removed from the exclusive jurisdiction of a state may be ordered by that state within its discretion, and other states may not intervene within that field of state competence.

The court also suffers from another kind of resistance and this is the resistance which is demonstrated towards the ICJ also, namely, the unwillingness of states to submit legal issues to international adjudication. While there are several possible explanations for this attitude, once again the problem may be attributed predominantly to the reluctance of states to consign might not be predictable. Thus, the contentious jurisdiction of the Inter American Court is optional and depends upon the consent of states. In this sense therefore, the Inter American Court is not a very different position to that of its analogues.

\section{Political and Social Condition Influencing the Courts Use:}

It is perhaps in the realm of political and social factors that the reasons for the nonuse of the Court become most apparent. While one can point to a high degree of political homogeneity and social organization within the council of Europe which has by and large provided a stable milieu in which the European institutions for the protection of human rights have been able to function freely, this has not been so in the case of the OAS ${ }^{8}$. The divergence in political and social cultures between North America, the Caribbean, Central America and Latin America is considerable. In the past, the political landscape of the Americas has ranged from liberal democracy to totalitarianism of both right and left. The commitment to the caudillo ideal and the corresponding espousal of a military culture in a large number of Latin American states has not provided fertile ground for the protection of human rights. The predominantly right-wing military culture with its emphasis on conformity and obedience has resulted in some of the worst human right abuses of modern times. Thus the general political climate in much of the Western Hemisphere has not been conducive to the development of supranational mechanisms for the supervision and protection of human rights. The lack of trust not simply between regimes and their own people, but the lack of trust between states themselves, has neither encouraged nor facilitated the development of appropriate mechanism for, pr perhaps more pertinently, reliance on existing mechanisms of, human rights protection.

It must also not be forgotten that economic factors have an influence upon the use of the Court. Poverty, lack of education and lack of access to legal services within many OAS states make it unlikely that individuals whose rights have been violated will resort to the Commission and, ultimately, the court protection or redress. While little can be done about these factors in the short term, it has been suggested, that the Court could raise awareness of its existence through the judicious use of public relations efforts. Certainly the educational process, which is a function of the Commission within the inter- American human rights systems, would be an appropriate vehicle for elevating the visibility of the Court. Dwyer also suggest that the court might, as its Statute empowers it to do, ride circuit among the territories of the states parties, as the Courts presence in a particular state might generate its use. Perhaps a more practical suggestion which would raise the general level of awareness about the existence of the Court would be Buergenthal's suggestion that it be made an organ of the OAS and not remain simply a creature of the Convention. This would certainty bring the Court within the mainstream of the Inter-American system and would have the desirable effect of giving it an equal status with the other institutions of the OAS. It might also operate to focus the minds of various government leaders on the commitment to human rights which they or their predecessors have made and the potential for progress in ratifying the Convention?

\section{Lack of Individual Access to the Court and the Commission's Procedures:}

As we have already seen, it is impossible for either an individual or a state to invoke the contentious jurisdiction of the court directly. Persons falling within the groups designated by Article 44 must, before the Commission and then the court can become seized of an issue involving a violation of human rights, comply fully with the procedures contained in Articles 46 and 47 of the Convention. Furthermore, the Gallardo case makes it clear that states might not by-pass the Commission's procedures in contentious cases involving

\footnotetext{
${ }^{7}$ Scott Davidson, The Inter-American Court of Human Rights, Datmouth, 1992

${ }^{8}$ T. Meron, Human Rights in Internatonal Law (Oxford University Press, 1994).

${ }^{9}$ Thomas Burgenthal, The American Convention on Human Rights: Illusion and Hopes, 1971, 69, AJIL
} 
potential individual applications. The Court, it will be recalled, did leave open the question of whether the Commission's procedures might be circumvented in inter-state under Article 45. Unless however, an individual can persuade a third state to espouse his claim under Article 45, this potential avenue for a speedier from of redress is unlikely to be of much use. It is also possible that the political to deter such sates.

While one authority ${ }^{10}$ considers it to be anomalous to deny individuals the right to refer a case to the Court since the Courts jurisdiction was created to protect individuals human rights, nonetheless, there exist good legal and policy reasons for limiting individual access to the Court due to the following reasons. First, the dominant issue is one of acknowledging state sovereignty. Direct individual access to a judicial institution without the opportunity for the state to settle the dispute either by way of local remedies or a friendly settlement would be unacceptable to most states which would see this as a virtual abandonment of domestic jurisdiction. Second, the commission acts as a filter to determine whether or not cases are properly founded. While it is always open to the Court to strike out a case that is an abuse of process, it is perhaps more convenient for the Commission to undertake such a task. Third, an absence of restriction on access to the Court might result in a proliferation of cases necessitating a restructuring of the Court including its division into chambers. It would probably also be difficult to obtain state agreement to such a radical restructuring, especially with the financial implications involved.

It may however be remarked that the court missed the opportunity in Gallardo ${ }^{11}$ to make a small but significant step in the direction of expediting individual access. Here, Costa Rica wished to waive the preconditions established within the Convention concerning admissibility of a case in order to take the question in issue directly before the Court. Its motivation for so doing was to secure a speedy judicial decision in the case in question. The court, it will be recalled, refused to permit direct access because, inter alia, failure to comply with the conditions governing procedures before the commission might damage victim's interest in securing a friendly settlement. The disagreement of Judge Piza Escalante with this argument has already been referred to above, but it is worth once again pointing to his view that the Commission's procedures are an impediment to effective protection of human rights. To use his words, the Commission's procedures are a veritable obstacle course that is almost insurmountable. While it might not be desirable to extend direct access to the Court by individuals, there would seem to be no pressing objection to allowing a state to waive Commission procedures and take an individual case directly to the Court with the consent of a potential petitioner. It is the issue of consent to which the Court did not allude in the Gallardo case which might prove decisive in such circumstances ${ }^{12}$.

\section{The Inter-American System: An Evaluation}

A Dynamic Mechanism:

Like the UN charter, the OAS Charter included a reference to human rights as one of the principles of the Organization. Article 5(j) of the Charter provides: the American States proclaim the fundamental rights of the individual without distinction as to race, nationality, creed or sex. Nowhere, however, did the Charter define what was meant by the phrase fundamental rights of the individual, nor did it provide any mechanism for the supervision or enforcement of those rights. This was partially remedied by the adoption at the same Bogota conference of the American Declaration of the Rights and Duties of Man, but like its UN analogue, the Universal Declaration of Human Rights, the American Declaration was not intended to be legally binding per se nor by incorporation in the Charter system.

\section{Binding Character of The Resolutions \& The Court Decisions:}

One of the features which distinguishes American system of human rights protection from other regional mechanisms is the obligatory character of the decisions and resolutions of its different organs. More specifically, the recommendations of the Human Rights Commission, the judgements of the Court and the resolutions of the different political bodies all share one common character of the obligatory nature. By ratifying the charter of the Organization of American States automatically undertake the obligation under the American Convention of Human Rights or other instruments. It thus paves the way for the civil society and NGOs to point at the failure of the sate concerned to fulfill its obligation under the relevant instruments. The Inter-American human rights system derives its spirit and organizational value mainly from the very obligatory nature of the resolutions of its political bodies, the Commission's recommendations, and the judgments of the Court. "The political bodies of the OAS, along with the Commission and the Court, all lack coercive means to compel state implementation of a resolution of the General Assembly or the Permanent Council, a recommendation of the

\footnotetext{
${ }^{10}$ Smith, Rhona K.M , International Human Rights, 2003.

${ }^{11}$ IIACHR, GALLARDO et al., Resolution No. 13/83, COSTA RICA, June 30, 1983; OAS/Ser.L/V/II.61; Doc. 22, rev.1, 27 September 1983. Original: Spanish; pp. 49-53.

${ }^{12}$ A. S, Dewyer, The inter-American Court of Human Rights-Towards Establishing an Effective Regional Contentious Jurisdictions' 13
} Boston College International and Comparative Law Review 127. 
Commission, or even a judgment of the Court. However, no state may fully ignore such legal pronouncements without incurring a potentially significant political cost ${ }^{\prime 13}$. The root potentials of the Inter-American system emerge from this legal and political base. More concretely, due to the space provided by the obligatory nature of the different human rights instruments, NGOs can play a very vital role to obtain justice for human rights violations, address general human rights situations and strengthen the rule of law.

\section{Obtaining Justice in Individual Cases:}

A case of human rights violation can only be taken to the American system, when all the available domestic remedies are exhausted. The Court or the Commission must respect the national procedure to address the particular problem before accepting an allegation to investigate. The Commission and the Court have can recommend to the state concerned any way forward to dissolve the problem and even the Commission have the authority to make arrangement for amicable settlements. They may also issue judgments. Though the principle of exhaustion of remedy is present in any regional human rights organization, the Inter-American system of human rights adopts it differently. By doing the above functions with the principle of exhaustion of remedy, they facilitate to the administration of justice in three ways; "by obligating a state to investigate a violation and punish those responsible; by ordering a state to pay monetary or symbolic reparations; or by ordering the implementation of appropriate legislative, administrative or other reforms to eradicate a practice that has been found to violate human rights" ${ }^{\prime \prime 14}$. These remedies are able to make a significant improvement the System as a whole. Most importantly, the Court or the Commission can make precautionary or provisional actions in order to protect the victims or witnesses.

\section{Rectifying a General Situation of Human Rights:}

The Inter-American system also observes human rights situations in the member states individually, and in respect of particular categories of rights across the region, such as the indigenous peoples, rights of children and women, migrant workers or in the area of freedom of expression thereby the system is promoting the human rights culture at the political as well as societal level. Good enough, the Commission apart from preparing reports on the general human rights situation in a particular country, can do in loco (on sight) investigation upon the consent of that state. This particular characteristic distningushe the System from the others; this allows the Commission to investigate and ensure the participation of the national NGOs and the civil societies and successfully leads to prepare a genuine and true report. The empirical study shows that the Commission is able to create an environment of respect to individual rights and dignity through its use of monitoring authority and strengthen non-governmental organizations to keep an eye on the activities of the government itself. A report on the Commission's visit to a particular country may also intensify pressure on that country to improve its human rights practices. "A Commission report, published after the Commission's in loco visit to Argentina, put an end to enforced disappearances in Argentina. A Commission report on Mexico, drafted after a visit to that country by the Reporter on the Rights of Women, led Mexico to establish new mechanisms to address the generalized situation of impunity for violence against women. And following a 1979 Commission report on the situation in Nicaragua, it was concluded that the government of Nicaragua had violated human rights in a grave, persistent and generalized manner, the Consultation of Foreign Ministers, a political body of the OAS, called for the immediate and definitive replacement of the Nicaraguan regime of Anastasio Somoza." 15

\section{Strengthening the Rule of Law:}

Another vigour of the Inter-American System is strengthening the rule of law. While dealing with the individual cases, the System not only offers damages for the violations occurred to the individual, but also pointing at the additional possibility of legislative reforms to curve on additional abuses in the country concerned, or at the regional level generally. Despite the fact that the states are bound to modify their national laws in conformity with the Convention rights, they continue with the domestic laws unchanged on various occasions; these laws may be discussed by the Inter-American system when considering individual cases. As is the case in reality, the development of the strong human rights base is imperative given the situations where the military regimes rise on a frequent basis in Latin America. There are some occasions where the member states adopted or modified their laws in accordance with the recommendations of the Council and the Court. For example, Costa Rica signed an agreement with the Court to give full effect to the decisions of the Court as in the decisions of the domestic courts. The Constitution of Honduras states that "Honduras embraces international law principles and practices espousing human solidarity, the self-determination of peoples, non-intervention and commitment to universal peace and democracy. Honduras declares the inevitable validity and obligatory

\footnotetext{
${ }^{13}$ I. Brownlie, Principles of Public International Law, Oxford university Press, $4^{\text {th }}$ Edition, 1990.

14 "Using Inter-American System of Human Rights" A Report published by "Global Rights"( an INGO) in March 2004.

${ }^{15}$ Schreiber, Anna P, The Inter - American Commission on Human Rights, 1970.
} 
execution of international arbitral or legal judgments. ${ }^{, 16}$ Article 30 of the Venezuela Constitution also speaks of the human rights protection to be ensured in accordance with the provisions of the OAS Human Rights Convention.

\section{Institutional Strengths \& Weaknesses of the American Convention:}

One of the best things that the American Convention brought out to protect international human rights is the innovation of private petition. Unlike the traditional view, it enables the Commission to entertain the private petition by individuals in respect of the human rights violations without requiring the states further to ratify the Convention. On the other hand, inter-state complaint system is pending to the states' acceptance of the jurisdiction of the Commission to investigate such complaints. Given the diplomatic relations, states are very reluctant to take the case to the Commission. Since the private petition is entertainable by the Commission upon the states' ratification of the Convention, private individuals who are victims of human rights violation by the state party, can take the problem straight to the Commission without facing the problem of hampering the diplomatic relations. However, one of the lacunae of the enforcement machinery as established by the Convention is that no institution was created with the power and functions like the counterpart of the European System namely the Constitutional Assembly of the Council of Europe-a body consisting of elected parliamentarians. This Assembly has definitely played a very important role in developing the conscience of the Europe leading to the effectiveness of the European Convention. This type of the body is much felt within the American Organization; the absence of a similar kind of human rights lobby with strong domestic political influence undoubtedly cast a negative influence on the whole Inter-American human rights effort. ${ }^{17}$

\section{OAS and EC Human Rights Protection Mechanisms: A Comparison}

The Inter-American system differs in many ways from the European human rights system. The InterAmerican system of human rights system is more complex than that of the European Convention in that it is based upon two overlapping institutions, namely the American Declaration on the Rights and Duties of Man and the American Convention. It has also more than one dimension in that the American Commission not only hears petitions from but also conducts on site visits leading to the adoption of the country reports on the human rights situations in OAS member states. This second limb adds a very important dimension to the Inter-American Commission's work having no counterpart in the European system. A crucial difference does exist at the stage of enforcing final decisions and judgements. The Inter-American system provides no counterpart to the supervisory role of the Committee of Ministers of the Council of Europe. Related to this is the fact the outcome of proceedings in the inter-American system is not necessarily a legally binding decision. The judgements of the inter-American Court are legally binding upon the parties. Moreover, there have been few signs that the Commission or the Court are following the national law standards common to the Americas. To the contrary, it is noticeable that the Court has stated that a certain tendency to integrate the regional and universal system for the protection of human rights can be perceived in the Convention. In accordance with such an approach, both the Court and the Commission have referred to the jurisprudence of the European Court and the Commission of human rights where necessary. By contrast, the European Court and the Commission tend to set their standards quite openly by reference to the law in the great majority of European states.

\section{Conclusion}

It might well be argued that before there can be meaningful development in the field of human rights, there must be social and political progress to provide the appropriate structures for individuals to seek redress in cases of rights violations. While there may be some truth in this, it is also apparent that international human rights institutions, if they undertake their task judiciously, can contribute to rather than retard such progress. The Inter-American Court of Human Rights appears to understand this role fully and has so far executed its mandate with sensitivity and discretion.

\section{Bibliography}

[1]. S, Dewyer, The inter-American Court of Human Rights-Towards Establishing an Effective Regional Contentious Jurisdictions' 13 Boston College International and Comparative Law Review 127.

[2]. Article 15 of The Constitution of Honduras

[3]. Article 25 of the European Convention.

[4]. Brownlie, Principles of Public International Law, Oxford university Press, $4^{\text {th }}$ Edition, 1990.

[5]. IIACHR, GALLARDO et al., Resolution No. 13/83, COSTA RICA, June 30, 1983; OAS/Ser.L/V/II.61; Doc. 22, rev.1, 27 September 1983. Original: Spanish; pp. 49-53.

[6]. Schreiber, Anna P, the Inter - American Commission on Human Rights, 1970.

[7]. Scott Davidson, the Inter-American Court of Human Rights, Datmouth, 1992

\footnotetext{
${ }^{16}$ Article 15 of The Constitution of Honduras.

17 Thomas Buergenthal, The American Convention on Human Rights.: Illusions and Hopes, 21 Buffelo Law review. 121, 130-31 (1971).
} 
[8]. Smith, Rhona K.M, International Human Rights, 2003.

[9]. T. Meron, Human Rights in Internatonal Law (Oxford University Press, 1994).

[10]. Thomas Burgenthal, the revised OAS Charter and the protection of human Rights, (1975) American Journal of international Law.

[11]. Thomas Buergenthal, The American Convention on Human Rights.: Illusions and Hopes, 21 Buffelo Law review. 121, 130-31 (1971).

[12]. "Using Inter-American System of Human Rights" A Report published by "Global Rights"( an INGO) in March 2004

[13]. Willem-Jan Van Der Wolf, Indigenous Peoples Rights in International Law, 4 Global Journal of Human Rights Review,87,107(1991). 